\title{
Development of Student Worksheet of Processing Plastic Waste into Biogas Based on Environmental Chemistry Lesson
}

\author{
Taty Sulastry \\ Faculty of Science \\ Universitas Negeri Makassar \\ Makassar, Indonesia
}

\author{
Ernawati S. Kaseng \\ Faculty of Science \\ Universitas Negeri Makassar \\ Makassar, South Sulawesi, Indonesia
}

\author{
Gufran Darma Dirawan \\ Faculty of Science \\ Universitas Negeri Makassar \\ Makassar, South Sulawesi, Indonesia
}

\begin{abstract}
This research is a development (Research and Development) model, which aims to develop the student worksheet on the processing of waste plastics into fuel oil and biogas production based environments valid, effective, and practical for use in the subject of environmental chemistry. Students' Worksheet development refers to Four-D model comprising the steps define, design, develop, and disseminate. The instrument in this study is based on the validity of instruments students' worksheet, the students' worksheet effectiveness instrument consists of instruments of learning outcomes and student activity observation sheet, as well as practicality students' worksheet instrument. It consists of a questionnaire of perception of students and faculty. The tests showed that the students' worksheet in the category valid. Students' worksheet also entered into force based on learning outcomes data and observation of student activities, while based on data from questionnaires the perception of students and faculty, students' worksheet otherwise practical for use.
\end{abstract}

Keywords-development research; development model 4D; students' worksheet

\section{INTRODUCTION}

Environmental education is support for the achievement of sustainable development in a nation. Therefore, all levels of education in Indonesia are required to implement environmental education. Environmental education as an effort to build human awareness around the world to care for the environment. This concern develops with knowledgeable capital on environmental issues. Concern can also be increased through the skills to solve environmental problems. Commitment to environmental conservation must be established at all ages [1][2].

Students in higher college education should be given knowledge and understanding about the environment. Furthermore, they can be change agents in the society in promoting sustainable environmental practices later. It is parallel with the aimed of environmental chemistry course that improves students understanding of the environment so that they become aware of the importance of preserving the environment and be able to practice skills in managing the environment in public life.
Based on the facts, an environmental course in university especially in UNM, the environmental chemistry courses have not been strong promoted environmental protection. There are still many students have not been able to show a real step in the processing environment. One reason is the teaching of environmental chemistry courses that do not provide the opportunity for students to apply science and knowledge that they have in the form of concrete activities in the processing environment. One real step processing environment conducted through experiments. Event experiments can be used to practice the skills that students need, giving students the opportunity to practice as well as integrate the knowledge and expertise they have signed in practice, prove something scientifically, and appreciate the knowledge and skills possessed.

One of the environmental problems in Indonesia is the volume of plastic waste. The utilization of plastic waste into useful materials can be a learning material in environmental education. In chemistry students, the application of materials to utilise plastic waste into biogas is an improvement of students' skills and attitudes to participate in reducing waste problems.

One type of experimental tasks which can be applied to the subject of the chemical environment, in particular on the material soil is the processing of waste plastics into biogas production. [3]-[5].

One of the references in the development of learning models was introduced by Sivasailam Thiagarajan, Dorothy S. Semmel, and Melvyn I. Semmel [6]. This model consists of four stages that are define, design, develop and disseminate or 4-D. The description of the steps is presented in Table 1.

It is necessary to develop a valid, effective, and practical students' worksheet in the processing of waste plastics into biogas production in environmental chemistry.

\section{RESEARCH METHOD}

This research is a model of development which refers to the development of 4D model that consists of four steps includes the defining, design, development and the disseminate. The 
research subject of Science Faculty Universitas Negeri Makassar (FMIPA UNM) students majoring in chemistry ICP class of 2013. The instruments used in this research consists of the post-test, student activity observation sheet to see the effectiveness, questionnaire, and observer to see the practice of developing worksheet. Data were processed by quantitative descriptive analysis method.

TABLE 1. THE 4-D ACTIVITIES

\begin{tabular}{|l|l|}
\hline Step & \multicolumn{1}{|c|}{ Activity } \\
\hline \multirow{3}{*}{ Define } & Front end analysis \\
\cline { 2 - 2 } & Learner analysis \\
\cline { 2 - 2 } & Concept analysis \\
\cline { 2 - 2 } & Task analysis \\
\cline { 2 - 2 } & specifying instructional objectives \\
\hline \multirow{2}{*}{ Design } & $\begin{array}{l}\text { constructing a criterion-referenced } \\
\text { test }\end{array}$ \\
\cline { 2 - 2 } & media selection \\
\cline { 2 - 2 } & initial design \\
\hline \multirow{2}{*}{ Develop } & expert appraisal \\
\cline { 2 - 2 } & developmental testing \\
\hline Disseminate & Customer analysis \\
\cline { 2 - 2 } & Media dissemination \\
\hline
\end{tabular}

\section{RESULT AND DISCUSSION}

\section{A. Stage defining (define)}

Front end analysis is the activity to establish basic problems in learning. Environmental chemistry teaching in the chemistry department FMIPA UNM is students are less able to apply the knowledge in concrete activities. While, the learner analysis activity resulted that students only understand the theory of environmental chemistry, therefore, they do not care about the environment.

The task and concept analysis resulted that the syllabus to achieve competence in the matter of land contamination and a special environmental case that must be done by the students is working on writing students' worksheet, and then students practice defend the idea that should be presented to the class. Researchers developed a method of assignment experiments on this material.

The last activity in the design stage is specifying instructional objectives. The main objective to be achieved in the development of Students' worksheet is the students can perform experiments processing of waste plastics into biogas production.

\section{B. Stage Design}

The development of reference test is based on students' cognitive abilities and learning objectives. This reference test as a lattice grid interpretation of learning. The steps of preparing the benchmark reference test are:
- Preparation of the lattice grid containing the subject matter as well as the expected cognitive achievements. Also specified is the number of test items for each aspect of cognition.

- Prepare a description of the problem by the aspects of the lattice grid.

- Analyze the rationality of each test, whether by students' cognitive abilities.

- Testing questions on students

- Analyze the reliability of the question

- Revise the test

- Provide evaluation support components

- Implementation of the test

- Evaluate test results

\section{Development phase}

Aspects of the physical appearance obtaining the average value of the validity of the three experts of 3.33 and are categorised as "Valid." These aspects include the appearance of Students' worksheet in general, use of typeface, and clarity of writing. The students' worksheet rated the appearance of the display cover, layout, graphics, and colour combinations.

Linguistic aspects include the ease of understanding the information in the students' worksheet, compliance with Indonesian Rule is good and right, the clarity of the language used, and the use of punctuation. All of these criteria are declared valid by the experts with an average value of 3.06 validity.

Content aspects include the material contained in the students' worksheet, the ease of using the students' worksheet and its role in helping students perform experiments biogas production obtain 3.00.

Based on validation result from three experts, student worksheet in biogas production had 3.13 point and categorised as valid. (Figure 1)

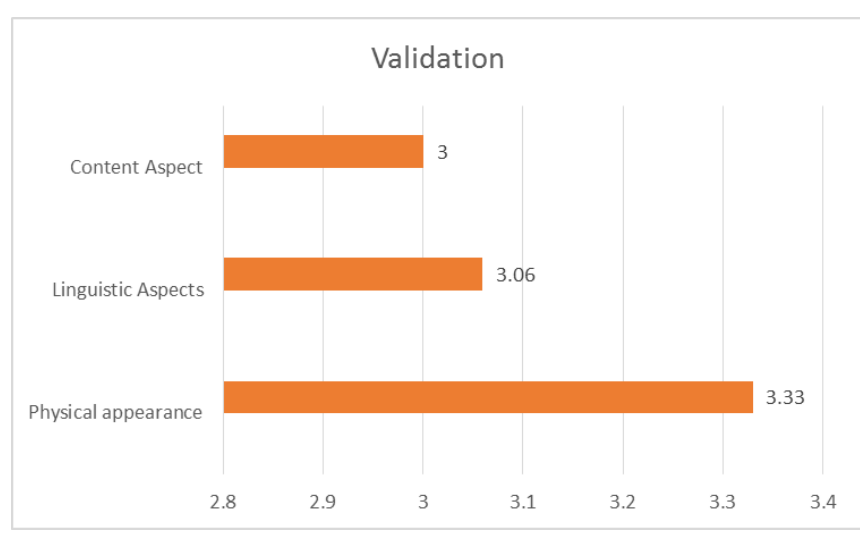

Fig 1. Value of validation result of three aspects 


\section{Disseminate phase}

Students' worksheet that has been declared valid by experts, then tested on an actual class.

Based on this research, $93.94 \%$ student is in the excellent category. These results indicate students' worksheet of biogas production effectively used to enhance the students' learning activities. The high percentage of student activity caused by the enthusiasm and passion of students doing experiments biogas production.

Practicality questionnaires consist of four aspects of the 20 statements. The first aspect in the questionnaire is the aspect of physical appearance Students' worksheet which includes general appearance, the use of font types and sizes, as well as the clarity of text and images. This aspect of obtaining a positive response from the students by $98.15 \%$ and categorised as very practical.

The second aspect is language in students' worksheet. This aspect is considered to be effectively and efficiently by students; it can be shown that the percentage of positive responses obtained is $94.44 \%$, so for this aspect categorised as very practical.

A further aspect is the content dimension of the students' worksheet. This aspect is convenient categorised based on the percentage of positive responses from students, which is $95.24 \%$. Students' worksheet rated very well for improving the creativity of students in the experiment. Issues raised in the students' worksheet are problems related to everyday life is a problem caused by organic waste.

The last aspect is the aspect of motivation also got a good response from students with a percentage of $92.36 \%$. Students are interested in conducting experiments because the materials used are materials easily obtained from the environment and do not require huge costs.

The average percentage of positive responses obtained from whole aspects is $95.05 \%$ so that it categorised as very practical to be used as teaching materials for environmental chemistry courses.

Results from 2 lecturers obtained a positive response by $100 \%$ so that Students worksheet are also categorised as very practical to use regarding the perception of lecturers.

Based on suggestions, comments, and feedback obtained from the questionnaire was repeated revisions of some components to developed the Students' worksheet. Information on biogas production is also added in the discourse to make students more aware of what they have to do when doing experiments, but it also added information reading material so that they can look for in the literature about the process biogas production. To look more attractive students' worksheet added and page footer in the students' worksheet.

Based on the results obtained prototype final revision of the development of the micro finance institution processing of waste plastics into biogas production based environments valid, efficient and practical to be used as teaching materials for environmental chemistry courses. Students' worksheet already can have applied in a different class and by various people.

\section{CONCLUSIONS}

This phase is carried out by four steps, namely the end of the preliminary analysis, analysis of student, task analysis, and concepts, as well as formulate learning objectives. (2) The design phase. The design phase is performed through three steps, namely designing experimental activities, determine the assessment strategy, and design the students' worksheet. (3) The development stage. At this stage, the students' worksheet validation followed by revisions based on suggestions and feedback from the experts. (4) The disseminate phase. At this stage, limited trial use of Students' worksheet in the actual class. The results of the validation student worksheet by three lecturers stated students' worksheet valid for use. Students' worksheet also declared effective for use based on the assessment of learning outcomes and student activity observation, while depending on the results of questionnaires the perception of students and faculty, Students' worksheet otherwise practical for use.

\section{REFERENCES}

[1] P. Chapman, "Environmental Education and Sustainability.," Indep. Sch., vol. 73, no. 4, p. n4, 2014.

[2] M. Somerville, "Environmental and sustainability education: a fragile history of the present," Sage Handb. Curriculum, Pedagog. Assessment. Vol. 1, pp. 506-522, 2016.

[3] R. Mohee, G. D. Unmar, A. Mudhoo, and P. Khadoo, "Biodegradability of biodegradable/degradable plastic materials under aerobic and anaerobic conditions," Waste Manag., vol. 28, no. 9, pp. 1624-1629, 2008.

[4] P. Weiland, "Biogas production: current state and perspectives," Appl. Microbiol. Biotechnol., vol. 85, no. 4, pp. 849-860, 2010.

[5] D. Deublein and A. Steinhauser, Biogas from waste and renewable resources: an introduction. John Wiley \& Sons, 2011.

[6] S. Thiagarajan, "Instructional Development for Training Teachers of Exceptional Children: A Sourcebook.," 1974. 